\title{
Conformational Analysis of Spiro-Bis- Dithiepins: a Peculiar Case of Axial Chirality
}

\author{
Edmir Wade, Roman A. Valiulin, Leslie Ruybal and Andrei G. Kutateladze*
}

\section{SUPPORTING INFORMATION}

Unless otherwise specified, solvents and reagents were purchased from commercial suppliers and used without further purification. THF was refluxed over and distilled from potassium benzophenone ketyl prior to use. ${ }^{1} \mathrm{H}$ and ${ }^{13} \mathrm{C}$ spectra were recorded at ambient temperature on Varian Mercury $400 \mathrm{MHz}$ spectrometer. In $\mathrm{CDCl}_{3}$, TMS was used as an internal standard. UVvis spectra were recorded using DU Series 600 Spectrometer (Beckman Instruments, Inc) with 1 $\mathrm{cm}$ length quartz cells at $1 \times 10^{-4}$ to $5 \times 10^{-4}$ concentrations. Column chromatography was performed on silica gel 200-240 mesh ASTM using ethyl acetate-hexanes mixtures unless otherwise specified. Mass spectrometry was performed on Bruker Reflex IV MALDI-TOF/MS.

Tetraacetyl pentaerythrithiol: To a $250 \mathrm{~mL}$ round bottom flask was added $12 \mathrm{~g}$ (31mmol) of pentaerythrityl tetrabromide and $14.26 \mathrm{~g}(124 \mathrm{mmol}, 4 \mathrm{eq})$ of potassium thioacetate in $100 \mathrm{~mL}$ of DMF. The resulting mixture was stirred for 16 hours. The excess DMF was removed under reduced pressure. The resulting oil was washed with water and extracted with dichloromethane (50 mL x 3). The organic layers were combined and dried over anhydrous sodium sulfate. The anhydrous sodium sulfate was filtered and the excess solvent was removed under reduced pressure. The resulting black oil was re-dissolved in 80/20 dichloromethane/methanol and refluxed for $10 \mathrm{~min}$ with activated charcoal. The charcoal was filtered off and the excess solvent removed under reduced pressure. The resulting solid was recrystallized from methanol to yield $9.1 \mathrm{~g}(80 \%)$ tetrathioacetate. ${ }^{1} \mathrm{H}$ NMR $\left(400 \mathrm{MHz}, \mathrm{CDCl}_{3}\right) \delta 3.04(\mathrm{~s}, 8 \mathrm{H}), 2.36(\mathrm{~s}, 12 \mathrm{H}) ;{ }^{13} \mathrm{C}$ NMR 194.0, 42.5, 34.9, 30.8 .

2,4,6,10-Tetrathiaspiro[5.5] undecane: To a $25 \mathrm{~mL}$ round bottom flask was added $0.475 \mathrm{~g}$ $(1.3 \mathrm{mmol})$ of tetraacetyl pentaerythrithiol, $10 \mathrm{~mL}$ of formaldehyde and $1 \mathrm{~mL}$ of concentrated hydrochloric acid. The resulting mixture was refluxed overnight. After completion, the reaction was neutralized with sodium bicarbonate solution and extracted with dichloromethane ( $15 \mathrm{~mL} \mathrm{x}$ 2 ). The organic layers were combined and dried over anhydrous sodium sulfate. Sodium sulfate was filtered and the excess solvent was removed under reduced pressure. The resulting solid was recrystallized from methanol to yield $0.2 \mathrm{~g}(68 \%)$ of 2,4,6,10-tetrathiaspiro[5.5]undecane. ${ }^{1} \mathrm{H}$ NMR (400 MHz, CDCl3) $\delta 3.66(\mathrm{~s}, 4 \mathrm{H}), 2.95(\mathrm{~s}, 8 \mathrm{H}) ;{ }^{13} \mathrm{C} \mathrm{NMR} 38.6,32.2,24.9$. 
3,9-Dimethyl-2,4,8,10-tetrathiaspiro[5.5] undecane (1): Method $A$ : $1.0 \mathrm{~g}$ (4.5mmol) of 2,4,6,10-tetrathiaspiro[5.5] undecane was dissolved in $30 \mathrm{~mL}$ of freshly distilled THF. The solution was cooled under nitrogen to $-25^{\circ} \mathrm{C}$. To this solution, $6 \mathrm{~mL}(9.8 \mathrm{mmol}, 1.6 \mathrm{M})$ of butyllithium was added and the resulting mixture stirred for $2 \mathrm{hr}$ at $-25^{\circ} \mathrm{C}$. $1.4 \mathrm{~g}(9.8 \mathrm{mmol})$ of methyl iodide was added and the solution was stirred for $1 \mathrm{hr}$. The reaction mixture was washed with equal volumes of water and a saturated aqueous ammonium chloride and extracted with dichloromethane $(15 \mathrm{ml} \times 2)$. The organic layers were combined and dried over anhydrous sodium sulfate. The excess solvent was removed under reduced pressure to afford a white solid. The white solid was recrystallized from methanol to give $1.1 \mathrm{~g}(98 \%)$ of 3,9-dimethyl-2,4,6,10tetrathiaspiro[5.5] undecane (3). Method B: $2 \mathrm{~g}(5.4 \mathrm{mmol})$ of tetraacetyl pentaerythrithiol and $4.18 \mathrm{~g}(21.6 \mathrm{mmol}, 4 \mathrm{eq})$ of $p$-toluenesulfonic acid were dissolved in $100 \mathrm{~mL}$ of ethanol upon heating. $0.99 \mathrm{~g}$ (11 mmol, $2 \mathrm{eq})$ of 1,1-dimethoxyethane was added and refluxed for 24 hours.

The excess ethanol was removed under reduced pressure to give clear oil, which was washed with water and extracted with dichloromethane $(20 \mathrm{~mL} \times 2)$. The organic layers were combined and dried over anhydrous sodium sulfate. The excess dichloromethane was removed under reduced pressure. The residue was recrystalized from methanol to give $0.93 \mathrm{~g}(69 \%)$ of 3,9dimethyl-2,4,6,10-tetrathiaspiro[5.5] undecane. Method $C: 53.25 \mathrm{~g}$ of NaSH and $31.5 \mathrm{~g}$ of sulfur were combined in $259 \mathrm{~mL}$ of $\mathrm{DMF}$ and heated at $80^{\circ} \mathrm{C}$ for 1 hour. After one hour the temperature was reduced to $40^{\circ} \mathrm{C}$ at which point $50 \mathrm{~g}(0.130 \mathrm{mmol})$ of pentaerythrityl tetrabromide was added and the mixture warmed to $80^{\circ} \mathrm{C}$ for 1 hour. Excess DMF was removed under reduced pressure and the resulting black oil was refluxed for 2 hours in toluene with $100 \mathrm{~g}$ of copper powder. Black solid was filtered off and an equal volume of ethanol was added. This solution was kept in an oil bath and $122.6 \mathrm{~g}$ of zinc dust was added. To this mixture, $500 \mathrm{~mL}$ of concentrated hydrochloric acid was added dropwise over the course of 2 hours. After additional stirring for 1.5 hours, $28.13 \mathrm{~g}$ of 1,1-dimethoxyethane was added. The reaction was warmed to $70^{\circ} \mathrm{C}$ and stirred overnight. The solution was filtered, the toluene layer was separated and dried over anhydrous sodium sulfate after which the solvent was removed under reduced pressure. The residue was recrystallized from methanol resulting in $20.2 \mathrm{~g}(64 \%)$ of product, 1 . ${ }^{1} \mathrm{H}$ NMR $\left(400 \mathrm{MHz}, \mathrm{CDCl}_{3}\right) \delta 4.04(\mathrm{q}, 2 \mathrm{H}, J=6.95 \mathrm{~Hz}), 3.82(\mathrm{~d}, 4 \mathrm{H}, J=12.98 \mathrm{~Hz}), 2.88(\mathrm{~d}, 4 \mathrm{H}, J=$ $14.09 \mathrm{~Hz}), 2.63(\mathrm{~d}, 4 \mathrm{H}, J=14.78 \mathrm{~Hz}), 2.50(\mathrm{~d}, 4 \mathrm{H}, J=14.08 \mathrm{~Hz}), 1.50(\mathrm{~d}, 6 \mathrm{H}, J=6.95 \mathrm{~Hz}) ;{ }^{13} \mathrm{C}$ NMR 42.61, 42.08, 35.79, 22.81, 20.32;

General Procedure for Preparation of Bis-adducts 3: Butyllithium (5 mL, $8 \mathrm{mmol}, 1.6 \mathrm{M}$ ) was added to $0.5 \mathrm{~g}$ (2 mmol) of 3,9-Dimethyl-2,4,6,10-tetrathia-spiro[5.5] undecane $\mathbf{1}$ and the mixture was stirred at room temperature for $30 \mathrm{~min}$. After that, a solution of a substituted benzaldehyde $(4.4 \mathrm{mmol})$ in $10 \mathrm{~mL}$ of freshly distilled THF was added to the mixture. The resulting mixture was stirred for $2 \mathrm{hr}$ at room temperature, washed with $20 \mathrm{~mL}$ of saturated $\mathrm{NH}_{4} \mathrm{Cl}(\mathrm{aq})$ and extracted with dichloromethane $(20 \mathrm{~mL} \times 2)$. Organic layers were combined and dried over anhydrous sodium sulfate. The solvent was removed under reduced pressure and the crude product was purified by column chromatography, (ethyl acetate: hexanes, 1:10, unless indicated otherwise).

(3,9-Dimethyl-2,4,8,10-tetrathiaspiro[5.5] undecan-3-yl)(phenyl)methanol(2a) ${ }^{1} \mathrm{H}$ NMR (400 $\left.\mathrm{MHz}, \mathrm{CDCl}_{3}\right) \delta$ 7.48-7.46 (m, 2H), 7.34-7.26 (m, 3H), $5.01(\mathrm{~s}, 1 \mathrm{H}), 4.03(\mathrm{q}, 1 \mathrm{H}, J=7.2 \mathrm{~Hz})$, 3.56-3.52 (m, 2H), $2.99(\mathrm{~d}, 1 \mathrm{H}, J=14.4 \mathrm{~Hz}), 2.89(\mathrm{~d}, 3 \mathrm{H}, J=14 \mathrm{~Hz}), 2.72-2.67(\mathrm{~m}, 2 \mathrm{H}), 2.45(\mathrm{~d}$, $1 \mathrm{H}, J=14.4 \mathrm{~Hz}), 1.51(\mathrm{~d}, 3 \mathrm{H}, J=7.2 \mathrm{~Hz}), 1.37(\mathrm{~s}, 3 \mathrm{H}) ;{ }^{13} \mathrm{C} \mathrm{NMR} 137.68,128.66,128.33$, 127.62, 74.83, 55.81, 42.87, 41.44, 38.87, 36.85, 31.79, 24.17, 22.56, 20.53. (3,9-Dimethyl- 
2,4,8,10-tetrathiaspiro[5.5]undecane-3,9-diyl)bis-(phenylmethanol) 3a, yield $60 \%$. ${ }^{1} \mathrm{H}$ NMR (400 MHz, $\left.\mathrm{CDCl}_{3}\right) \delta$ 7.51-7.47 (m, 4H), 7.36-7.25 (m, 6H), $5.02(\mathrm{~s}, 2 \mathrm{H}), 3.32-3.26(\mathrm{~m}, 2 \mathrm{H})$, 3.13-2.88 (m, 4H), 2.63-2.52 (m, 2H), $1.38(\mathrm{~s}, 6 \mathrm{H}) ;{ }^{13} \mathrm{C}$ NMR 137.68, 128.66, 128.39, 127.68, $75.21,75.01,55.70,37.79,37.08,33.43,32.78,25.10,22.70$.

(3,9-Dimethyl-2,4,8,10-tetrathiaspiro[5.5]undecan-3-yl)(4-cyano phenyl)methanol(2b) ${ }^{1} \mathrm{H}$ NMR (400 MHz, CDCl3) $\delta 7.75(\mathrm{~m}, 2 \mathrm{H}), 7.39(\mathrm{~m}, 2 \mathrm{H}), 5.01(\mathrm{~s}, 1 \mathrm{H}), 4.03(\mathrm{q}, 1 \mathrm{H}, J=6.8 \mathrm{~Hz})$, 3.56-3.52 (m, 2H), 3.39 (br, 1H), 3.03-2.84 (m, 3H) 2.70-2.62 (m, 2H), 2.39-2.35 (m, 1H), 1.47 (d, 3H, $J=6.8 \mathrm{~Hz}), 1.24(\mathrm{~s}, 3 \mathrm{H})$. (3,9-Dimethyl-2,4,8,10-tetrathiaspiro[5.5] undecane-3,9diyl)bis-(4-cyanophenylmethanol) $3 \mathbf{b}$ : yield $25 \% \quad{ }^{1} \mathrm{H} \mathrm{NMR}\left(400 \mathrm{MHz}, \mathrm{CDCl}_{3}\right) \delta 7.75$ (m, 2H), 7.39 (m, 2H), 5.02 (s, 2H), 3.32-3.26 (m, 2H), 3.13-2.88 (m, 4H), 2.63-2.52 (m, 2H), 1.38 $(\mathrm{s}, 6 \mathrm{H})$.

(3,9-Dimethyl-2,4,8,10-tetrathiaspiro[5.5] undecan-3-yl)(3-cyano phenyl)methanol(2c) ${ }^{1} \mathrm{H}$ NMR (400 MHz, CDCl3) $\delta 7.75(\mathrm{~s}, 1 \mathrm{H}), 7.68(\mathrm{~m}, 1 \mathrm{H}), 7.54(\mathrm{~m}, 1 \mathrm{H}), 7.39(\mathrm{t}, 1 \mathrm{H}, J=15.6 \mathrm{~Hz})$, $5.01(\mathrm{~s}, 1 \mathrm{H}), 4.03(\mathrm{q}, 1 \mathrm{H}, J=6.8 \mathrm{~Hz}), 3.56-3.52(\mathrm{~m}, 2 \mathrm{H}), 3.39(\mathrm{br}, 1 \mathrm{H}), 3.03-2.84(\mathrm{~m}, 3 \mathrm{H}) 2.70-$ $2.62(\mathrm{~m}, 2 \mathrm{H}), 2.39-2.35(\mathrm{~m}, 1 \mathrm{H}), 1.47(\mathrm{~d}, 3 \mathrm{H}, \mathrm{J}=6.8 \mathrm{~Hz}), 1.24$ (s, 3H). (3,9-Dimethyl-2,4,8,10tetrathiaspiro[5.5] undecane-3,9-diyl)bis-(3-cyanophenylmethanol) 3c: yield 35\%. ${ }^{1} \mathrm{H}$ NMR $\left(400 \mathrm{MHz}^{\mathrm{CDCl}} 3\right) \delta 7.75(\mathrm{~s}, 1 \mathrm{H}), 7.68(\mathrm{~m}, 1 \mathrm{H}), 7.54(\mathrm{~m}, 1 \mathrm{H}), 7.39(\mathrm{t}, 1 \mathrm{H}, J=15.6 \mathrm{~Hz}), 5.02(\mathrm{~s}$, $2 \mathrm{H}), 3.32-3.26(\mathrm{~m}, 2 \mathrm{H}), 3.13-2.88(\mathrm{~m}, 4 \mathrm{H}), 2.63-2.52(\mathrm{~m}, 2 \mathrm{H}), 1.38(\mathrm{~s}, 6 \mathrm{H})$.

(3,9-Dimethyl-2,4,8,10-tetrathiaspiro[5.5] undecan-3-yl)(pyridyl)methanol(2d) $\quad{ }^{1} \mathrm{H} \quad \mathrm{NMR}$ $(400 \mathrm{MHz}, \mathrm{CDCl} 3) \delta 7.75(\mathrm{~s}, 1 \mathrm{H}), 7.68(\mathrm{~m}, 1 \mathrm{H}), 7.54(\mathrm{~m}, 1 \mathrm{H}), 7.39(\mathrm{t}, 1 \mathrm{H}, J=15.6 \mathrm{~Hz}), 5.01(\mathrm{~s}$, $1 \mathrm{H}), 4.03(\mathrm{q}, 1 \mathrm{H}, J=6.8 \mathrm{~Hz}), 3.56-3.52(\mathrm{~m}, 2 \mathrm{H}), 3.39(\mathrm{br}, 1 \mathrm{H}), 3.03-2.84(\mathrm{~m}, 3 \mathrm{H}) 2.70-2.62(\mathrm{~m}$, 2H), 2.39-2.35 (m, 1H), $1.47(\mathrm{~d}, 3 \mathrm{H}, J=6.8 \mathrm{~Hz}), 1.24(\mathrm{~s}, 3 \mathrm{H})$. (3,9-Dimethyl-2,4,8,10tetrathiaspiro[5.5] undecane-3,9-diyl)bis-(pyridylmethanol) $3 \mathrm{~d}$ : yield $40 \%$. ${ }^{1} \mathrm{H}$ NMR (400 $\left.\mathrm{MHz}, \mathrm{CDCl}_{3}\right) \delta 7.75(\mathrm{~s}, 1 \mathrm{H}), 7.68(\mathrm{~m}, 1 \mathrm{H}), 7.54(\mathrm{~m}, 1 \mathrm{H}), 7.39(\mathrm{t}, 1 \mathrm{H}, J=15.6 \mathrm{~Hz}), 5.02(\mathrm{~s}, 2 \mathrm{H})$, 3.32-3.26 (m, 2H), 3.13-2.88 (m, 4H), 2.63-2.52 (m, 2H), $1.38(\mathrm{~s}, 6 \mathrm{H})$.

2e-i and 3e-i were introduced into the second step, i.e. dehydrative ring expansion, without further purification.

Deuterated water quenching experiments to optimize the formation of dianion: the dianion was generated as described above. $1 \mathrm{~mL}$ aliquots were removed every 15 min with a Hamilton syringe and quenched with $\mathrm{D}_{2} \mathrm{O}$. The resulting solution was extracted with chloroform. The chloroform was removed under reduced pressure and the sample re-dissolved in $\mathrm{CDCl}_{3}$ for $\mathrm{NMR}$ determination of the H-D exchange.

General Procedure for the Preparation of Bis-dithiepines 5 (except for $5 \mathbf{f f}): 0.1 \mathrm{~g}(0.2 \mathrm{mmol})$ of bis-adduct 2 was dissolved in toluene and a catalytic amount of p-toluenesulfonic acid (0.1eq) was added. The reaction mixture was refluxed with the Dean-Stark trap for 12 hours. The mixture was allowed to cool to room temperature and the excess toluene was removed under reduced pressure. The resulting oil was washed with saturated $\mathrm{NH}_{4} \mathrm{Cl}(\mathrm{aq})$ and extracted with dichloromethane $(15 \mathrm{~mL} \times 2)$. The organic extracts were combined and dried over anhydrous sodium sulfate, the solvent was removed under vacuum and the crude residue was chromatographed, silica gel, ethyl acetate - hexane, 1:10. 
3,10-Dimethyl-4,11-diphenyl-2,5,9,12-tetrathiaspiro[6.6]trideca-3,10-diene(5a): Yield 90\%. ${ }^{1} \mathrm{H}$ NMR (400 MHz, CDCl3) $\delta$ 7.33-7.25 (m, 10H), 3.48 (br, 8H), 1.70 (s, 6H).

3,10-Dimethyl-4,11-di-(4-cyanophenyl)-2,5,9,12-tetrathiaspiro[6.6]trideca-3,10-diene(5b): Yield 80\%. ${ }^{1} \mathrm{H}$ NMR (400 MHz, $\left.\mathrm{CDCl}_{3}\right) \delta 7.59$ (m, 4H), 7.41 (m, 4H), 3.48 (br, 8H), 1.70 (s, $6 \mathrm{H})$.

3,10-Dimethyl-4,11-di-(3-cyanophenyl)-2,5,9,12-tetrathiaspiro[6.6]trideca-3,10-diene(5c): Yield 84\%. ${ }^{1} \mathrm{H}$ NMR (400 MHz, $\left.\mathrm{CDCl}_{3}\right) \delta$ 7.60-7.39 (m, 8H), 3.48 (br, 8H), $1.70(\mathrm{~s}, 6 \mathrm{H})$.

\section{3,10-Dimethyl-4,11-di-(4-methoxyphenyl)-2,5,9,12-tetrathiaspiro[6.6]trideca-3,10-diene}

(5g): Yield 92\%. ${ }^{1} \mathrm{H}$ NMR (400 MHz, CDCl3) $\delta 7.21(\mathrm{~d}, 4 \mathrm{H}, J=6.4 \mathrm{~Hz}), 6.77$ (d, 4H, $J=$ $6.4 \mathrm{~Hz}), 3.81(\mathrm{~s}, 3 \mathrm{H}), 3.45(\mathrm{br}, 8 \mathrm{H}), 1.71(\mathrm{~s}, 6 \mathrm{H})$.

3,10-Dimethyl-4,11-di-(4-bromophenyl)-2,5,9,12-tetrathiaspiro[6.6]trideca-3,10-diene (5h): Yield 80\%. ${ }^{1} \mathrm{H}$ NMR (400 MHz, CDCl3) $\delta$ 7.42-7.25 (m, 8H), 3.48 (br, 8H), $1.70(\mathrm{~s}, 6 \mathrm{H})$.

3,10-Dimethyl-4,11-di-(4-t-butyldimethylsilyloxyphenyl)-2,5,9,12-tetrathiaspiro[6.6]trideca3,10-diene (5e): Yield 80\%. ${ }^{1} \mathrm{H}$ NMR (400 MHz, CDCl 3$\left.) \delta 7.13(\mathrm{~d}, 4 \mathrm{H}) \quad \mathrm{Hz}\right), 6.77(\mathrm{~d}, 4 \mathrm{H})$ $\mathrm{Hz}), 3.45$ (br, 8H), 1.71 (s, 6H), 0.98 (s, 9H), 0.20 (s, 6H).

3,10-Dimethyl-4,11-di-(trimethoxyphenyl)-2,5,9,12-tetrathiaspiro[6.6]trideca-3,10-diene (5i): purified by column chromatography (ethyl acetate: hexanes, 1:10). Yield 95\%.

${ }^{1} \mathrm{H}$ NMR $\left(400 \mathrm{MHz}, \mathrm{CDCl}_{3}\right) \delta 6.8(\mathrm{~s}, 4 \mathrm{H}), 3.84$ (s, 9H), 3.48 (br, 8H), $1.70(\mathrm{~s}, 6 \mathrm{H})$.

3,10-Dimethyl-4,11-di-(4-carboxyphenyl)-2,5,9,12-tetrathiaspiro[6.6]trideca-3,10-diene (5f). Butyllithium $(5 \mathrm{~mL}, 8 \mathrm{mmol}, 1.6 \mathrm{M})$ was added to a solution of dimethyl spiro-bis-dithiane 1 $(0.50 \mathrm{~g}, 2 \mathrm{mmol})$ in $40 \mathrm{~mL}$ of freshly distilled THF at room temperature and stirred under nitrogen for $30 \mathrm{~min}$. After $30 \mathrm{~min}$ a solution of terephthaldehyde mono diethyl acetal (1.03 g, $4.4 \mathrm{mmol}$ ) in $10 \mathrm{~mL}$ of freshly distilled THF was added to the mixture and stirred for $2 \mathrm{hr}$ at room temperature. The mixture was then washed with a saturated solution of ammonium chloride $(20 \mathrm{~mL})$ and extracted with dichloromethane $(30 \mathrm{~mL}$ x 2). The organic layers were combined and dried over anhydrous sodium sulfate. The solvent was removed under reduced pressure to yield orange oil. Without further purification the oil was dissolved in an $80 \%$ aqueous acetic acid and refluxed for $2 \mathrm{hr}$, cooled to room temperature, after which the solvent was removed under reduced pressure. Saturated solution of sodium bicarbonate was added and the product was extracted with dichloromethane $(20 \mathrm{~mL} \times 2)$. The organic layers were combined and dried over anhydrous sodium sulfate. The solvent was removed under reduced pressure to give a yellow solid, which was dissolved in toluene upon heating, and $p-\mathrm{TsOH}(0.1$ eq) was added to the solution. The mixture was refluxed for $12 \mathrm{hr}$ using a Dean Stark trap. After cooling the toluene solution was washed with a saturated aqueous of sodium bicarbonate, and aqueous layer was extracted with dichloromethane $(20 \mathrm{~mL} \times 2)$. The organic phases were combined and the solvent was removed in vacuum. The reaction mixture was separated using column chromatography (10:1 hexane:ethyl acetate) to yield $0.53 \mathrm{~g}(55 \%)$ of bis-aldehyde $(5 \mathbf{f}) .{ }^{1} \mathrm{H} \mathrm{NMR}$ $\left(400 \mathrm{MHz}, \mathrm{CDCl}_{3}\right) \delta 10.00(\mathrm{~s}, 2 \mathrm{H}), 7.84(\mathrm{~d}, 4 \mathrm{H}, J=8.2 \mathrm{~Hz}), 7.45(\mathrm{~d}, 4 \mathrm{H}, J=8.2 \mathrm{~Hz}), 3.50$ (br, $8 \mathrm{H}), 1.72(\mathrm{~s}, 6 \mathrm{H}) ;{ }^{13} \mathrm{C}$ NMR 191.63, 147.43, 135.39, 130.75, 129.69, 43.82, 42.16, 38.57, 37.62, 35.92, 31.72, 23.92, 20.27; (MALDI-TOF) calcd for $\mathrm{C}_{25} \mathrm{H}_{25} \mathrm{O}_{2} \mathrm{~S}_{4}(\mathrm{MH}+$ ) 485.07, found 485.12. 
Mono-dithiepins 4 were prepared from the respective mono-adducts $\mathbf{2}$ under the same procedures.

Monoaldehyde 4f: ${ }^{1} \mathrm{H}$ NMR (400 MHz, $\left.\mathrm{CDCl}_{3}\right) \delta 10.00(\mathrm{~s}, 1 \mathrm{H}, \mathrm{CHO}), 7.84(\mathrm{~d}, 4 \mathrm{H}, J=8.2 \mathrm{~Hz})$, $7.45(\mathrm{~d}, 4 \mathrm{H}, J=8.2 \mathrm{~Hz}), 4.00(\mathrm{q}, 1 \mathrm{H}, J=6.4 \mathrm{~Hz}), 3.84$ (d, 2H, $J=9.40 \mathrm{~Hz}), 3.36-3.20$ (m, 2H, $\left.\mathrm{CH}_{2}\right), 3.01(\mathrm{~d}, 2 \mathrm{H}, J=13.9 \mathrm{~Hz}), 2.80(\mathrm{~d}, 2 \mathrm{H}, J=13.9 \mathrm{~Hz}), 1.73(\mathrm{~d}, 3 \mathrm{H}, J=3.58 \mathrm{~Hz}), 1.51(\mathrm{~d}$, $3 \mathrm{H}, J=6.4 \mathrm{~Hz})$.

General Procedure for Preparation of Compounds 6-8: Bis-aldehyde 5 f was dissolved in pyridine with two equivalents of the desired active methylene compound (malonitrile, heptyl cyanoacetate, decyl cyanoacetate) and stirred for 2 days. Pyridine was removed under reduced pressure to furnish pure products quantitatively. Spiro-bis-dithiepin 6: ${ }^{1} \mathrm{H} \mathrm{NMR} \mathrm{(400} \mathrm{MHz,}$ $\left.\mathrm{CDCl}_{3}\right) \delta 8.1(\mathrm{~s}, 2 \mathrm{H}), 7.84(\mathrm{~d}, 4 \mathrm{H}, J=7.79 \mathrm{~Hz}), 7.45(\mathrm{~d}, 4 \mathrm{H}, J=7.98 \mathrm{~Hz}), 3.50(\mathrm{br}, 8 \mathrm{H}), 1.72(\mathrm{~s}$, $6 \mathrm{H})$; spiro-bis-dithiepin 7: ${ }^{1} \mathrm{H} \mathrm{NMR}\left(400 \mathrm{MHz}, \mathrm{CDCl}_{3}\right) \delta 8.1(\mathrm{~s}, 2 \mathrm{H}), 7.84(\mathrm{~d}, 4 \mathrm{H}, J=7.79 \mathrm{~Hz})$, 7.45 (d, 4H, $J=7.98 \mathrm{~Hz}), 3.50(\mathrm{br}, 8 \mathrm{H}), 2.5(\mathrm{~m}, 4 \mathrm{H}), 1.72-0.5(\mathrm{~m}, 36 \mathrm{H})$; spiro-bis-dithiepin 8: ${ }^{1} \mathrm{H}$ NMR (400 MHz, CDCl 3$) \delta 8.1(\mathrm{~s}, 2 \mathrm{H}), 7.84(\mathrm{~d}, 4 \mathrm{H}, J=7.79 \mathrm{~Hz}), 7.45$ (d, 4H, $\left.J=7.98 \mathrm{~Hz}\right)$, 3.50 (br, $8 \mathrm{H}), 2.5(\mathrm{~m}, 4 \mathrm{H}), 1.72-0.5(\mathrm{~m}, 48 \mathrm{H})$.

Typical procedures for Preparation of Bis-imines (9-11): Method A: $50 \mathrm{mg}(0.1 \mathrm{mmol})$ of the bis-aldehyde $5 \mathbf{f}$ was dissolved in $20 \mathrm{~mL}$ of benzene along with $0.043 \mathrm{~g}(0.2 \mathrm{mmol})$ of 4 heptyloxyaniline. To this mixture, $30 \mathrm{mg}(2.5 \mathrm{eq})$ of anhydrous magnesium sulfate was added and the reaction stirred for three hours. After three hours, the magnesium sulfate was filter off and benzene was removed under reduced pressure. The resulting solid was recrystallized from ether to yield the product. Yield 95\%. Method B: $0.1 \mathrm{~g}(0.2 \mathrm{mmols})$ of bis-aldehyde $5 \mathbf{f}$ was dissolved in $15 \mathrm{~mL}$ of toluene. $0.086 \mathrm{~g}(0.4 \mathrm{mmol})$ of 4-heptyloxyaniline was added to the solution. The resulting solution was refluxed at $110^{\circ} \mathrm{C}-120^{\circ} \mathrm{C}$ using an oil bath for with a DeanStark trap for two days. After two days the toluene was evaporated and the resulting solid was recrystalized from ether to yield $78 \mathrm{mg}(95 \%)$ of product. ${ }^{1} \mathrm{H} \mathrm{NMR}\left(400 \mathrm{MHz}, \mathrm{CDCl}_{3} \delta 8.46\right.$ (s, 2H), 7.84 (d, 4H, J ) $8.34 \mathrm{~Hz}$ ), 7.38 (d, 4H, J ) $8.25 \mathrm{~Hz}$ ), 7.22 (d, 4H, J ) $8.9 \mathrm{~Hz}), 6.92$ (d, 4H, J), $8.92 \mathrm{~Hz}), 3.98$ (t, 4H, J), $6.58 \mathrm{~Hz}), 3.50$ (br, 8H), 1.83-1.74 (m, 10H), 1.50-1.31 (m, 16H), 0.91$0.86(\mathrm{~m}, 6 \mathrm{H})$. MALDI-TOF: Calcd for $\mathrm{C}_{51} \mathrm{H}_{63} \mathrm{~N}_{2} \mathrm{O}_{2} \mathrm{~S}_{4}(\mathrm{MH}+)$ 863.37, found 863.24.

Imine 12: $100 \mathrm{mg}(0.2 \mathrm{mmol})$ of bis-aldehyde (5f) was dissolved in $15 \mathrm{~mL}$ of benzene. $50 \mathrm{mg}$ $(0.4 \mathrm{mmol})$ of $(R)-2$-phenylethylamine and $54 \mathrm{mg}(0.52 \mathrm{mmol})$ of anhydrous magnesium sulfate was added to the solution and stirred at room temperature overnight. Magnesium sulfate was filtered off and benzene was removed under reduced pressure. The resulting solid was recrystallized from methanol to yield pure $5 \mathbf{f}$ (35\% after recrystallization). ${ }^{1} \mathrm{H}$ NMR (400 MHz, $\left.\mathrm{CDCl}_{3}\right) \delta 8.35(\mathrm{~s}, 2 \mathrm{H}), 7.73(\mathrm{~m}, 4 \mathrm{H}), 7.45-7.20(\mathrm{~m}, 18 \mathrm{H}), 4.54(\mathrm{q}, 2 \mathrm{H}, J=6.7 \mathrm{~Hz}) 3.50(\mathrm{br}, 8 \mathrm{H})$, $1.7(\mathrm{~s}, 6 \mathrm{H}), 1.59(\mathrm{~d}, 6 \mathrm{H}, J=6.7 \mathrm{~Hz})$.

Tartrate bis-acetal 13: ${ }^{1} \mathrm{H}$ NMR $\left(400 \mathrm{MHz} \mathrm{CDCl}_{3}\right) \delta 7.54(\mathrm{~d}, 4 \mathrm{H}, J=8.2 \mathrm{~Hz}), 7.30(\mathrm{~d}, 4 \mathrm{H}, J=$ $8.2 \mathrm{~Hz}), 6.13(\mathrm{~s}, 2 \mathrm{H}), 4.94(\mathrm{~d}, 2 \mathrm{H}, J=4.0 \mathrm{~Hz}), 4.83(\mathrm{~d}, 2 \mathrm{H}, J=4.0 \mathrm{~Hz}), 4.33-4.29(\mathrm{q}, 8 \mathrm{H}, J=$ $7.3 \mathrm{~Hz}), 3.80-2.80(\mathrm{~m}, 8 \mathrm{H}), 1.68(\mathrm{~s}, 6 \mathrm{H}), 1.33(\mathrm{t}, 12 \mathrm{H}, J=7.3 \mathrm{~Hz})$.

Chiral Separation of $5 f$ on Chiracel OD column: injected at $1 \mathrm{mg} / 20 \mathrm{uL}$ ); flow rate 1.5 $\mathrm{mL} / \mathrm{min}$; eluent: hexanes - isopropanol, 9:1; $100 \mathrm{~min}$. 
Preparation of mono protected Acenaphthaquinone(15): A $100 \mathrm{~mL}$ round bottom flask was charged with $1.22 \mathrm{~g}(0.016 \mathrm{~mol}, 1 \mathrm{eq})$ of 1,3-propanediol, $3 \mathrm{~g}(0.016 \mathrm{~mol}, 1 \mathrm{eq})$ of $p$-TsOH , 3.0 $\mathrm{g}(0.016 \mathrm{~mol})$ of acenaphthaquinone in $50 \mathrm{~mL}$ of anhydrous benzene. The flask was outfitted with a Dean Stark trap and the reaction mixture was refluxed for $5 \mathrm{~h}$, cooled, washed with saturated aqueous sodium bicarbonated and dried over anhydrous sodium sulfate. The solvent was removed under reduced pressure and the resulting solid was purified by column chromatography (9:1 hexane:ethyl acetate) to yield $2.46 \mathrm{~g}$ of pure $13(64 \%)$. ${ }^{1} \mathrm{H}$ NMR (400 $\mathrm{MHz}, \mathrm{CDCl}_{3}, \delta 8.08(\mathrm{~d}, 1 \mathrm{H}, J=8.4 \mathrm{~Hz}), 7.91(\mathrm{~d}, 2 \mathrm{H}, J=7.6 \mathrm{~Hz}), 7.77-7.66(\mathrm{~m}, 3 \mathrm{H}), 5.03-4.96$ (m, 2H), 4.11-4.06 (m, 2H), 2.47-2.42 (m, 1H), 1.80-1.74 (m, 1H).

Spiro-bis-dithiepin 18 was synthesized from 15 according to general procedures above and purified by column chromatography (silica gel, 4:1 hexane:ethyl acetate) ${ }^{1} \mathrm{H}$ NMR (400 MHz, $\mathrm{CDCl}_{3}, \delta 8.54\left(\mathrm{dd}, 2 \mathrm{H}, J_{1}=1.39 \mathrm{~Hz}, J_{2}=7.25 \mathrm{~Hz}\right), 8.31(\mathrm{~d}, 2 \mathrm{H}, J=7.47 \mathrm{~Hz}), 8.2(\mathrm{~m}, 2 \mathrm{H}), 8.02$ $(\mathrm{d}, 2 \mathrm{H}, J=8.18 \mathrm{~Hz}), 7.74(\mathrm{t}, 2 \mathrm{H}, J=7.35 \mathrm{~Hz}), 7.61$ (t, 2H, $J=7.71 \mathrm{~Hz}), 3.68(\mathrm{br}, 4 \mathrm{H}), 3.52$ (br, $4 \mathrm{H})$. 
VT NMR EXPERIMENTS - $\Delta H^{\neq}$and $\Delta S^{\neq}$in (5f)

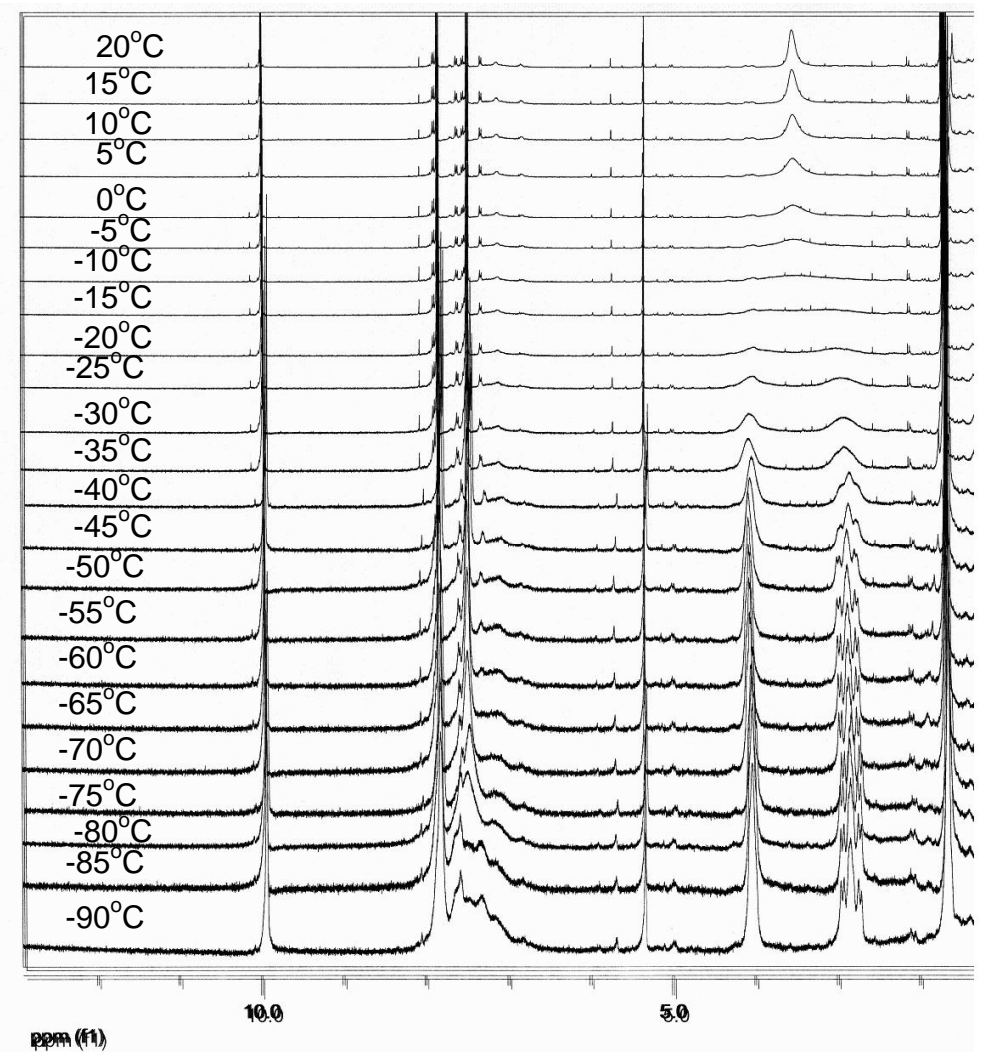

Spectra recorded between $-35^{\circ} \mathrm{C}$ and $20^{\circ} \mathrm{C}$ were used in determining the activation parameters for conformational change in $\mathbf{5 f}$. The coalescing multiplets at $4 \mathrm{ppm}$ and $2.8 \mathrm{ppm}$ were fitted to the following parameters.

Line shape of the resonance signal is given by (Günther, Harald; NMR Spectroscopy, John Wiley \& Sons, Ltd; New York, 1980, pp.238-239):

$g(v)=[(1+\tau \pi \Delta) P+Q R] /\left(4 \pi^{2} P^{2}+R^{2}\right)$

where

$\mathrm{P}=\left(0.25 \Delta^{2}-v^{2}+0.25 \delta v^{2}\right) \tau+\Delta / 4 \pi$

$\mathrm{Q}=\left[-\mathrm{v}-0.5\left(\mathrm{p}_{\mathrm{A}}-\mathrm{p}_{\mathrm{B}}\right) \delta \mathrm{v}\right] \tau$

$\mathrm{R}=0.5\left(\mathrm{p}_{\mathrm{A}}-\mathrm{p}_{\mathrm{B}}\right) \delta v-v(1+2 \pi \tau \Delta)$

$\tau=\tau_{\mathrm{A}} \tau_{\mathrm{B}} /\left(\tau_{\mathrm{A}}+\tau_{\mathrm{B}}\right)$

$\tau_{\mathrm{A}}, \tau_{\mathrm{B}}$ - average life time of the nuclei in positions $\mathrm{A}$ and $\mathrm{B}(\mathrm{s})$

$\mathrm{p}, \mathrm{p}_{\mathrm{B}}-$ molar fractions

$\delta v$ - difference between the resonance frequencies of the nuclei

$\Delta-\mathrm{FWHH}(\mathrm{Hz})$ in the absence of exchange; $\Delta_{\mathrm{A}}=\Delta_{\mathrm{B}}=\Delta$ for simplicity 
The spectrum represents two conformers syn and anti. The high field signal at $2.8 \mathrm{ppm}$ is in fact four doublets with $J=14.1 \mathrm{~Hz}: 2.952 \mathrm{ppm}, 2.864 \mathrm{ppm}, 2.843 \mathrm{ppm}, 2.749 \mathrm{ppm}$. For simplicity, the spectra were fit w/o fitting the actual four doublets, but rather using two limiting values of $\Delta$, $1 \mathrm{~Hz}$ and $15 \mathrm{~Hz}$.

(A) Rate constants data for simulation with $\Delta=1 \mathrm{~Hz}$

\begin{tabular}{|c|c|c|c|c|}
\hline C & $\mathrm{T}, \mathrm{K}$ & $1 / T$ & K & $\ln (k / T)$ \\
\hline-35 & 238.15 & 0.004199034 & 377 & 0.459344 \\
\hline-30 & 243.15 & 0.004112688 & 610 & 0.91978 \\
\hline-25 & 248.15 & 0.004029821 & 910 & 1.299411 \\
\hline-20 & 253.15 & 0.003950227 & 1250 & 1.596917 \\
\hline-15 & 258.15 & 0.003873717 & 1680 & 1.873008 \\
\hline-10 & 263.15 & 0.003800114 & 2900 & 2.399742 \\
\hline-5 & 268.15 & 0.003729256 & 4300 & 2.774824 \\
\hline 0 & 273.15 & 0.003660992 & 6450 & 3.161814 \\
\hline 5 & 278.15 & 0.003595182 & 8330 & 3.399458 \\
\hline 10 & 283.15 & 0.003531697 & 11800 & 3.729878 \\
\hline 15 & 288.15 & 0.003470415 & 14300 & 3.904534 \\
\hline \multirow[t]{4}{*}{20} & 293.15 & 0.003411223 & 20000 & 4.222803 \\
\hline & & $\Delta \mathrm{H} \neq$ & -9.6 & $\mathrm{kcal} / \mathrm{mol}$ \\
\hline & & $\Delta \mathbf{S} \neq$ & -6.0 & e.u. \\
\hline & & R2 & 0.997 & \\
\hline
\end{tabular}

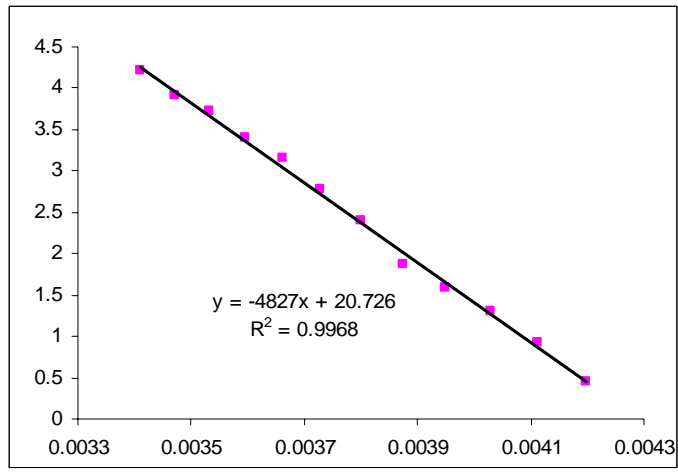

(B) Rate constants data for simulation with $\Delta=15 \mathrm{~Hz}$

\begin{tabular}{rrrrr} 
t, C & \multicolumn{1}{l}{$\mathrm{T}, \mathrm{K}$} & \multicolumn{1}{l}{$1 / \mathrm{T}$} & $\mathrm{k}$ & $\mathrm{In}(\mathrm{k} / \mathrm{T})$ \\
-35 & 238.15 & 0.004199 & 350 & 0.385032 \\
-30 & 243.15 & 0.004113 & 570 & 0.851958 \\
-25 & 248.15 & 0.00403 & 870 & 1.25446 \\
-20 & 253.15 & 0.00395 & 1230 & 1.580787 \\
-15 & 258.15 & 0.003874 & 1650 & 1.85499 \\
-10 & 263.15 & 0.0038 & 3100 & 2.466433 \\
-5 & 268.15 & 0.003729 & 4500 & 2.820286 \\
0 & 273.15 & 0.003661 & 7400 & 3.299214 \\
5 & 278.15 & 0.003595 & 10300 & 3.611739 \\
10 & 283.15 & 0.003532 & 15400 & 3.996146 \\
15 & 288.15 & 0.00347 & 21300 & 4.302981 \\
20 & 293.15 & 0.003411 & 28600 & 4.580478 \\
& & & & \\
& & $\Delta \mathbf{H} \neq$ & -10.8 & $\mathrm{kcal} / \mathrm{mol}$ \\
& & $\Delta \mathbf{S} \neq$ & -1.2 & $\mathrm{e} . \mathrm{u}$.
\end{tabular}

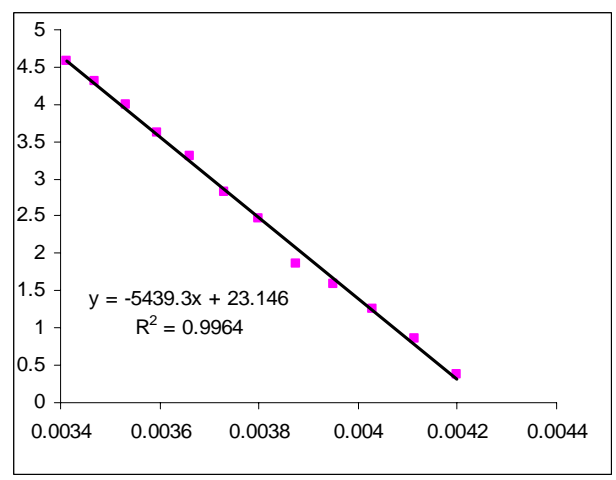


The averaged data was reported with the error defined within the limits of the two simulations:

\begin{tabular}{rrrrl} 
t, C & \multicolumn{1}{l}{ T,K } & \multicolumn{1}{l}{$1 / \mathrm{T}$} & $\mathrm{k}$ & $\mathrm{In}(\mathrm{k} / \mathrm{T})$ \\
-35 & 238.15 & 0.004199 & 363.5 & 0.422879 \\
-30 & 243.15 & 0.004113 & 590 & 0.886444 \\
-25 & 248.15 & 0.00403 & 890 & 1.277188 \\
-20 & 253.15 & 0.00395 & 1240 & 1.588884 \\
-15 & 258.15 & 0.003874 & 1665 & 1.86404 \\
-10 & 263.15 & 0.0038 & 3000 & 2.433643 \\
-5 & 268.15 & 0.003729 & 4400 & 2.797813 \\
0 & 273.15 & 0.003661 & 6925 & 3.232872 \\
5 & 278.15 & 0.003595 & 9315 & 3.511221 \\
10 & 283.15 & 0.003532 & 13600 & 3.871848 \\
15 & 288.15 & 0.00347 & 17800 & 4.123473 \\
20 & 293.15 & 0.003411 & 24300 & 4.417547 \\
& & & & \\
& & $\Delta \mathbf{H} \neq$ & -10.2 & $\mathrm{kcal} / \mathrm{mol}$ \\
& & $\Delta \mathbf{S \neq}$ & -3.5 & $\mathrm{e} . \mathrm{u}$.
\end{tabular}

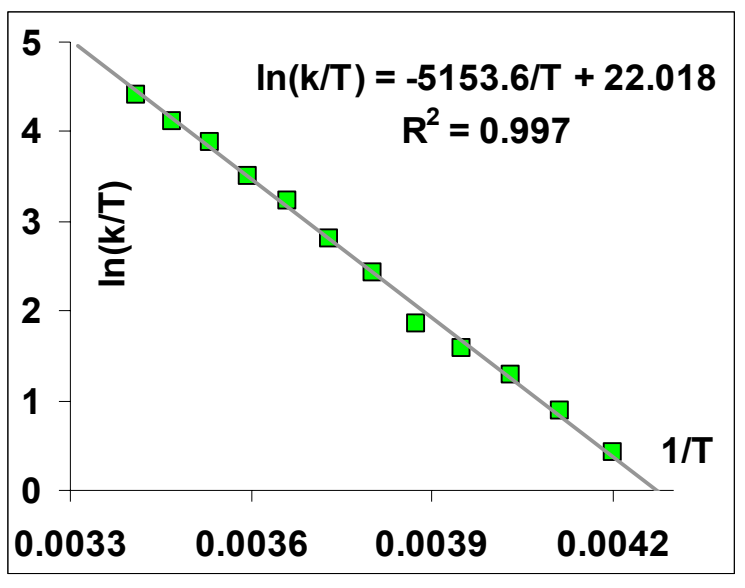




\section{COMPUTATIONAL DETAILS.}

$\mathrm{Ab}$ initio and DFT computations were carried out using Gaussian-03 Rev. C.02 package. The initial geometries were generated with Chem3D and pre-optimized at AM1 and HF levels of theory, after which a full geometry optimization was carried out at the B3LYP/6-31G(d) level of theory. The stationary points are characterized by vibrational analysis, i.e. all transition states have one imaginary frequency; all minima do not have imaginary frequencies. For unsubstituted spiro-bis-dithiepins the geometries and DFT energies are computed with a more advanced basis set 6-311++G(3df) without vibrational analysis.

\section{Conformers of unsubstituted spiro-bis-dithiepins (Figure 3)}

(Energy, Hartrees; Atomic Coordinates).

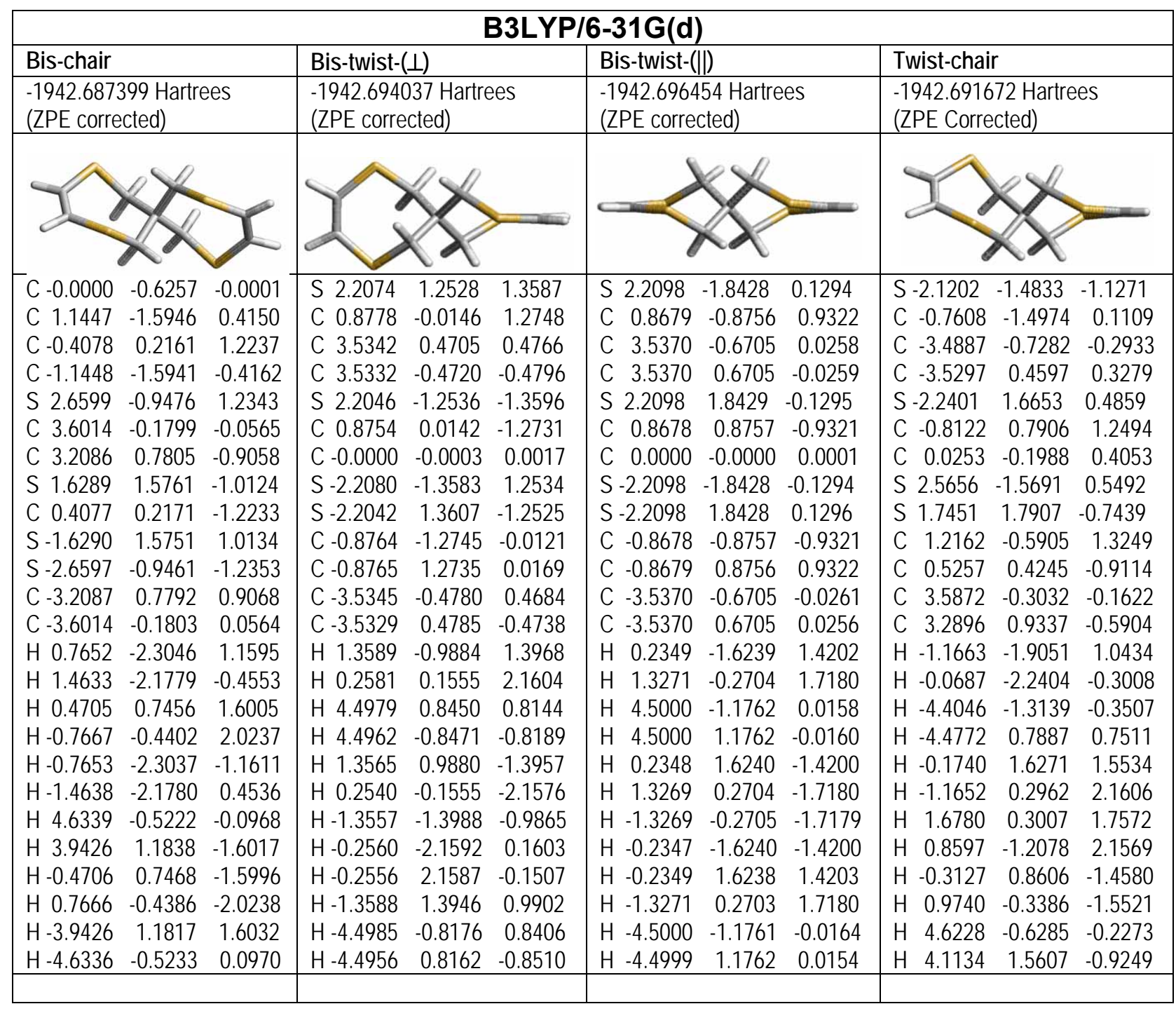




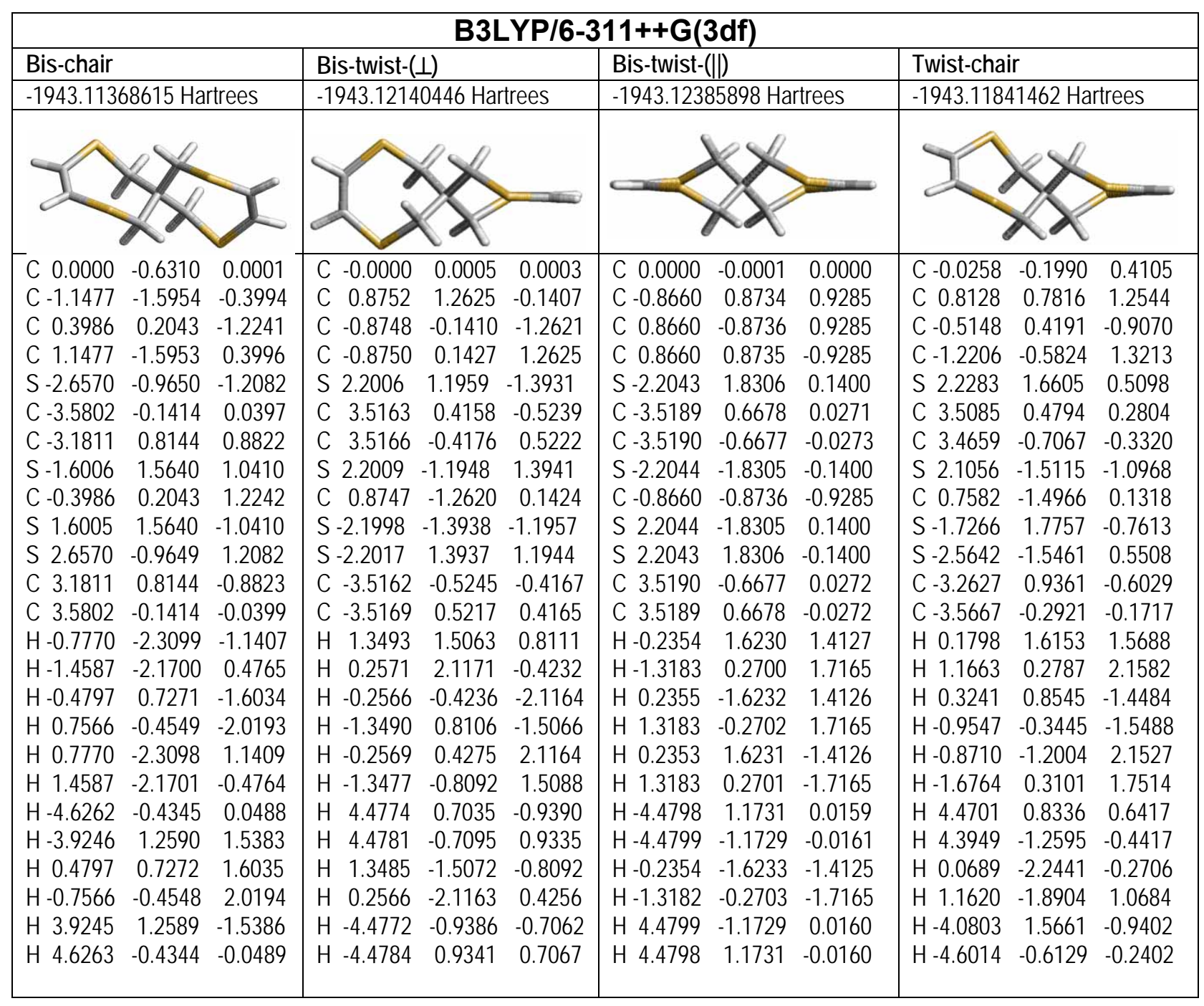

\section{Transition states TS1 and TS2 (Figure 3)}

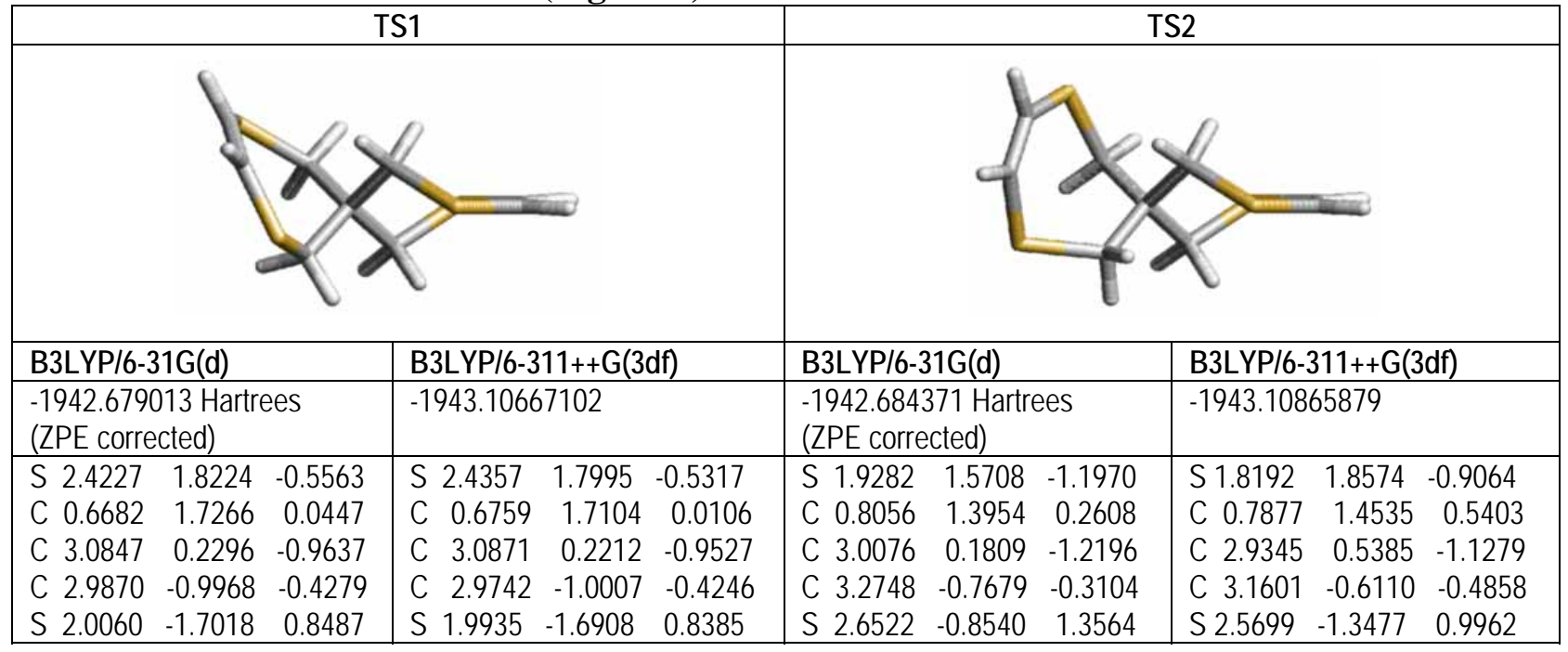




\begin{tabular}{|c|c|c|c|c|c|c|c|c|c|c|c|}
\hline C 0.8903 & .3786 & 4642 & C 0.8857 & -0.3764 & 4486 & C 0.8385 & -1.0529 & 1.1427 & C 0.7960 & -0.9683 & 1.3291 \\
\hline C 0.0011 & 0.3886 & 0.4465 & C 0.0014 & 0.3865 & 0.4321 & C 0.0119 & 0.0794 & 0.4329 & C 0.0146 & 0.1150 & 0.5611 \\
\hline S - 2.6508 & 1.5290 & 0.2468 & S - 2.6352 & 1.5305 & 0.2356 & .5213 & 1.4510 & 0.7189 & 800 & 1.3519 & 0.6712 \\
\hline S - 1.4535 & -1.8652 & -0.5689 & -1.4699 & -1.8539 & -0.5564 & -1.7404 & -1.7632 & -0.9114 & 1.5328 & -1.7425 & -0.9712 \\
\hline C - -1.3013 & 0.7483 & 1.2219 & 2921 & 0.7640 & 1.2050 & 328 & 0.3793 & 1.3803 & & 0.3296 & ..4127 \\
\hline 3566 & -0.4118 & -0.8234 & 3681 & -0.4236 & -0.82 & 97 & 55 & 38 & 97 & 81 & 603 \\
\hline 006 & 0.1097 & -0.4011 & C -3.4897 & 0.1219 & -0.3880 & 46 & 0.2877 & -0.1333 & 85 & 0.1933 & -0.3020 \\
\hline C -3.0696 & -1.1359 & -0.6573 & C -3.0699 & -1.1244 & -0.6303 & 46 & -0.9 & -0.6864 & 39 & 18 & -0.8594 \\
\hline H 0.6788 & 2.3839 & 0.9208 & H 0.6629 & 2.3926 & 0.8646 & 1.3595 & 1.6328 & 1.1700 & 3822 & 1.5536 & 1.4504 \\
\hline H 0.0571 & 2.2155 & -0.7191 & H 0.0866 & 2.1753 & -0.7812 & 0.0941 & 2.2076 & 0.0735 & 29 & 2.2805 & 0.5233 \\
\hline H 3.7972 & 0.3466 & -1.7779 & H 3.8048 & 0.3373 & -1.7597 & 08 & 0.1247 & -2.1847 & 108 & 0.7341 & -2.0086 \\
\hline H 3.6045 & -1.7770 & -0.8704 & H 3.5851 & -1.7854 & -0.8637 & 04 & -1.5443 & -0.5697 & 512 & -1.2397 & -0.8847 \\
\hline $\mathrm{H} \mathrm{C}$ & -0.9454 & 2.1574 & 2562 & -0.9419 & 2.1398 & & -2.0118 & 0.6548 & 550 & 9173 & 2295 \\
\hline 676 & 0.3320 & 2.0620 & H 1.4601 & 0.3330 & 2.0462 & 36 & -1.1648 & 2.1805 & 92 & -0.7081 & 2.3909 \\
\hline H - -1.7254 & -0.1487 & 1.6783 & -1.7165 & -0.1215 & 1.6776 & 6514 & -0.5530 & 1.7057 & .7105 & -0.6282 & 1.6834 \\
\hline H -1.0788 & 1.4531 & 2.0300 & H -1.0616 & 1.4791 & 1.9985 & -0.8206 & 0.8934 & 2.2776 & H - -1.0050 & 0.8413 & 2.3432 \\
\hline H 0.5385 & -0.8053 & -1.3055 & H 0.5183 & -0.8317 & -1.3040 & 3298 & -0.8053 & -1.5318 & 0.5243 & -0.6977 & -1.3926 \\
\hline H - 0.8546 & 0.2424 & -1.5426 & H -0.8610 & 0.2254 & -1.5465 & H -0.9315 & 0.4204 & -1.5128 & H -0.7781 & 0.4756 & -1.4365 \\
\hline H -4.5469 & 0.3364 & -0.5924 & H -4.5337 & 0.3525 & -0.5750 & H - -4.5829 & 0.6391 & -0.1770 & H - -4.5095 & 0.5089 & -0.4267 \\
\hline H -3.8082 & -1.8638 & -0.9864 & H -3.8135 & -1.8522 & -0.9408 & H - -4.1035 & -1.4761 & -1.0951 & H - -3.8672 & -1.5543 & -1.3544 \\
\hline
\end{tabular}

Bis-aldehyde 5f (B3LYP/6-31G(d)

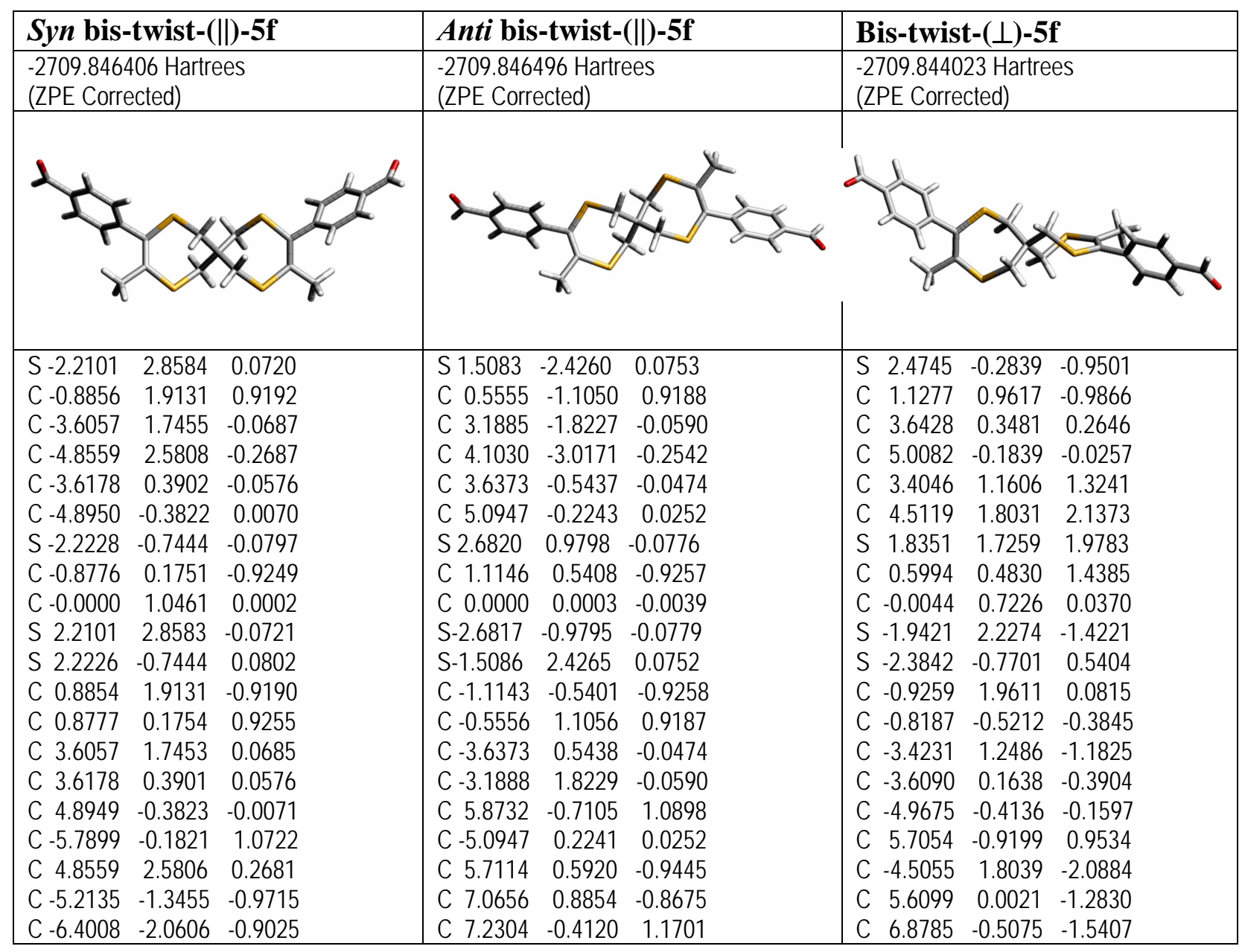




\begin{tabular}{|c|c|c|c|c|c|c|c|c|}
\hline C -6.9780 & -0.9041 & 1.1451 & C 7.8379 & 0.3856 & 0.1929 & C 6.9697 & -1.4322 & 0.6949 \\
\hline C - -7.2941 & -1.8463 & 0.1591 & C 9.2811 & 0.6978 & 0.2837 & C 7.5686 & -1.2279 & -0.5570 \\
\hline C - 8.5591 & -2.6091 & 0.2415 & O 9.8951 & 1.3758 & -0.5181 & C 8.9147 & -1.7713 & -0.8423 \\
\hline O -8.9210 & -3.4403 & -0.5694 & C -5.8732 & 0.7102 & 1.0898 & O 9.5862 & -2.4084 & -0.0529 \\
\hline C 5.2137 & -1.3454 & 0.9715 & C - 4.1034 & 3.0171 & -0.2541 & C -5.9994 & 0.3904 & 0.3645 \\
\hline C 5.7897 & -0.1823 & -1.0724 & C -5.7113 & -0.5923 & -0.9445 & C -5.2371 & -1.7682 & -0.4234 \\
\hline C $6.9778-$ & -0.9042 & -1.1453 & C - 7.2304 & 0.4115 & 1.1701 & C -6.5060 & -2.2921 & -0.1975 \\
\hline C $6.4010-$ & -2.0604 & 0.9025 & C - 7.0655 & -0.8858 & -0.8675 & C -7.2644 & -0.1336 & 0.5947 \\
\hline C 7.2942 & -1.8462 & -0.1592 & C - 7.8378 & -0.3861 & 0.1930 & C -7.5291 & -1.4819 & 0.3124 \\
\hline C 8.5591 & -2.6090 & -0.2418 & O -9.8949 & -1.3767 & -0.5180 & C -8.8741 & -2.0485 & 0.5542 \\
\hline O 8.9212 & -3.4401 & 0.5692 & C -9.2809 & -0.6985 & 0.2837 & O $\quad-9.8207$ & -1.4225 & 0.9924 \\
\hline H - 0.2751 & 2.6752 & 1.4146 & H - 0.2704 & -1.6303 & 1.4099 & H 1.5823 & 1.9443 & -0.8385 \\
\hline H -1.3492 & 1.3050 & 1.6995 & H 1.1855 & -0.6788 & 1.7033 & H 0.7331 & 0.9348 & -2.0070 \\
\hline H -5.1418 & 3.0982 & 0.6550 & H 4.2020 & -3.5993 & 0.6699 & H 4.5586 & 1.3827 & 3.1490 \\
\hline H -5.6983 & 1.9760 & -0.6074 & H 5.0972 & -2.7168 & -0.5881 & H 4.3188 & 2.8780 & 2.2491 \\
\hline H - 4.6725 & 3.3568 & -1.0231 & H 3.6825 & -3.6922 & -1.0108 & H 5.4868 & 1.6856 & 1.6621 \\
\hline H - 0.2631 & -0.5935 & -1.4053 & H 0.7823 & 1.4658 & -1.4086 & H 1.0727 & -0.5004 & 1.4926 \\
\hline H -1.3283 & 0.7786 & -1.7168 & H 1.3486 & -0.1773 & -1.7156 & H -0.1834 & 0.5091 & 2.2028 \\
\hline H 1.3488 & 1.3049 & -1.6994 & H -1.3485 & 0.1781 & -1.7156 & H -1.6045 & 1.9091 & 0.9363 \\
\hline H 0.2748 & 2.6752 & -1.4143 & H -0.7819 & -1.4649 & -1.4089 & H -0.3344 & 2.8753 & 0.1911 \\
\hline H 0.2633 - & -0.5930 & 1.4063 & H 0.2702 & 1.6311 & 1.4098 & H -0.2348 & -1.4327 & -0.2236 \\
\hline H 1.3286 & 0.7792 & 1.7170 & H -1.1854 & 0.6795 & 1.7032 & H -1.0682 & -0.4768 & -1.4476 \\
\hline H -5.5394 & 0.5369 & 1.8462 & H 5.4012 & -1.3161 & 1.8575 & H 5.2347 & -1.0929 & 1.9166 \\
\hline H 5.1417 & 3.0979 & -0.6558 & H 5.1151 & 0.9853 & -1.7616 & H -5.3521 & 1.1215 & -2.1760 \\
\hline H 5.6984 & 1.9759 & 0.6067 & H 7.5513 & 1.5007 & -1.6187 & H -4.1019 & 1.9718 & -3.0954 \\
\hline H 4.6727 & 3.3567 & 1.0225 & H 7.8231 & -0.7915 & 2.0000 & H -4.8700 & 2.7730 & -1.7270 \\
\hline H -4.5205 - & -1.5186 & -1.7886 & H 9.7959 & 0.2555 & 1.1659 & H 5.0776 & 0.5541 & -2.0508 \\
\hline H -6.6613 - & -2.7933 & -1.6602 & H -5.4013 & 1.3159 & 1.8575 & H 7.3412 & -0.3464 & -2.5122 \\
\hline H -7.6621 - & -0.7440 & 1.9759 & H -5.0975 & 2.7167 & -0.5881 & H 7.5104 & -2.0034 & 1.4435 \\
\hline H -9.1892 - & -2.3668 & 1.1265 & H -3.6830 & 3.6925 & -1.0104 & H 9.2952 & -1.5529 & -1.8652 \\
\hline H 4.5210 - & -1.5182 & 1.7890 & H - 4.2027 & 3.5991 & 0.6701 & H -5.7898 & 1.4299 & 0.5985 \\
\hline H 5.5392 & 0.5369 & -1.8463 & H -5.1150 & -0.9853 & -1.7618 & H -4.4466 & -2.4019 & -0.8122 \\
\hline H 7.6618 - & -0.7441 & -1.9763 & H - 7.8231 & 0.7908 & 2.0001 & H -6.7089 & -3.3380 & -0.4184 \\
\hline H 6.6617 & -2.7929 & 1.6603 & H -7.5511 & -1.5012 & -1.6187 & H -8.0629 & 0.4793 & 1.0017 \\
\hline H $9.1891-$ & -2.3667 & -1.1269 & H -9.7958 & -0.2563 & 1.1660 & H -8.9752 & -3.1271 & 0.2993 \\
\hline
\end{tabular}

Spiro diketone 18 (B3L YP/6-31G(d))

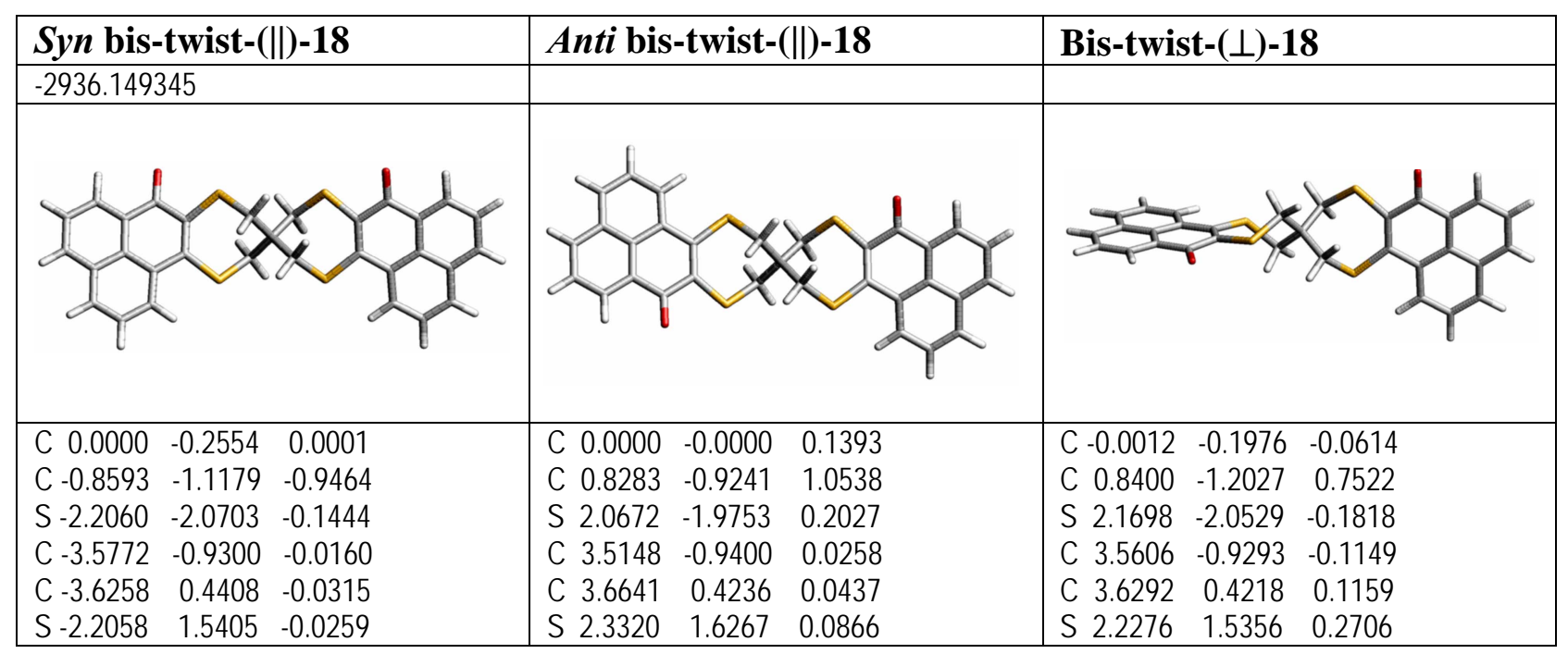




\begin{tabular}{|c|c|c|c|c|c|c|c|c|}
\hline C - 0.914 & 0.6110 & 0.8881 & C 0.9416 & 0.8020 & -0.7810 & C 0.9398 & 0.7810 & -0.7956 \\
\hline C 0.859 & -1.1181 & 0.9464 & C -0.8283 & 0.9241 & 1.0538 & C -0.8655 & -0.9514 & -1.0929 \\
\hline C - 4.922 & 1.1493 & -0.0704 & C 5.0107 & 1.0328 & 0.0458 & C 4.9364 & 1.0923 & 0.2782 \\
\hline C -4.819 & -1.7280 & 0.1748 & C 4.6860 & -1.8270 & -0.2093 & C 4.7929 & -1.7106 & -0.4086 \\
\hline S 2.205 & 1.5405 & 0.0264 & S -2.3320 & -1.6267 & 0.0866 & S - -2.3047 & -0.3799 & 1.5961 \\
\hline S 2.2060 & -2.0703 & 0.1443 & S - 2.0672 & 1.9753 & 0.2027 & S - 2.0930 & 0.0793 & -1.9851 \\
\hline C 0.914 & 0.6111 & -0.8878 & C -0.9416 & -0.8021 & -0.7810 & C - 0.9212 & 0.5962 & 0.8906 \\
\hline C 3.577 . & -0.9301 & 0.0161 & C - -3.5148 & 0.9400 & 0.0258 & C -3.5208 & 0.1186 & -0.9082 \\
\hline C 3.625 & 0.4408 & 0.0319 & C - -3.6641 & -0.4236 & 0.0437 & C -3.6530 & -0.1162 & 0.4375 \\
\hline O 4.755 & -2.9429 & -0.3612 & O -4.5246 & 3.0329 & -0.3985 & O -4.5494 & 0.8999 & -2.8858 \\
\hline C 4.922 & 1.1493 & 0.0706 & C -5.0107 & -1.0328 & 0.0458 & C -4.9910 & -0.1897 & 1.0607 \\
\hline C 6.112 & -1.0146 & -0.1181 & C - 6.0296 & 1.2125 & -0.1913 & C -6.0346 & 0.4257 & -1.0998 \\
\hline C 4.819 & -1.7280 & -0.1748 & C -4.6860 & 1.8270 & -0.2094 & C - -4.6990 & 0.5189 & -1.7249 \\
\hline C 7.293 & -1.7401 & -0.1917 & C - -6.1647 & -0.1904 & -0.0475 & C -6.1541 & 0.0606 & 0.2639 \\
\hline C 8.537 & -1.0889 & -0.1278 & C 7.4765 & 0.7568 & -0.0212 & C 7.4150 & 0.9582 & 0.2994 \\
\hline C 8.588 & 0.2846 & 0.0057 & C 7.1503 & -2.0234 & -0.3058 & C - 5.1801 & -0.5080 & 2.4030 \\
\hline C 7.402 & 1.0586 & 0.0787 & C -5.2158 & -2.4062 & 0.1480 & C 7.2663 & -1.7639 & -0.3969 \\
\hline C 6.138 . & 0.3954 & 0.0184 & C 6.5100 & 2.9656 & 0.1884 & C 6.3115 & 3.0594 & 0.7726 \\
\hline C 7.440 & 2.4722 & 0.1999 & C 8.4413 & -1.4675 & -0.2760 & C 8.5196 & -1.1522 & -0.2196 \\
\hline C 5.020 & 2.5348 & 0.1680 & C 6.0296 & -1.2125 & -0.1913 & C 5.0556 & 2.4448 & 0.5868 \\
\hline$C-6.112$ & -1.0146 & 0.1180 & O 4.5246 & -3.0329 & -0.3984 & C 6.0957 & -1.0376 & -0.2267 \\
\hline O - 4.755 & -2.9429 & 0.3613 & C 8.5990 & -0.1028 & -0.1352 & O 4.7124 & -2.8812 & -0.7805 \\
\hline C -6.138 & 0.3954 & -0.0184 & C 6.1647 & 0.1904 & -0.0475 & C - 7.4584 & -0.0310 & 0.8405 \\
\hline C 6.267 & 3.1899 & 0.2415 & C 7.6239 & 2.1625 & 0.1075 & C 6.1413 & 0.3341 & 0.1245 \\
\hline C - 5.020 & 2.5348 & -0.1680 & C - -7.4765 & -0.7568 & -0.0212 & C 8.5901 & 0.1839 & 0.1224 \\
\hline C - 7.293 & -1.7401 & 0.1915 & C - 6.5100 & -2.9656 & 0.1884 & C 7.4734 & 2.3360 & 0.6350 \\
\hline C - 7.402 & 1.0586 & -0.0790 & C - -7.1503 & 2.0234 & -0.3058 & C -7.1633 & 0.6906 & -1.8630 \\
\hline C - -8.537 & -1.0890 & 0.1274 & C - -7.6239 & -2.1625 & 0.1075 & C - 6.4673 & -0.6123 & 2.9703 \\
\hline C - -8.588 & 0.2846 & -0.0062 & C 5.2158 & 2.4062 & 0.1480 & C -8.4471 & 0.5963 & -1.2978 \\
\hline C -7.440 & 2.4722 & -0.2004 & C -8.4413 & 1.4675 & -0.2760 & C - 8.5895 & 0.2413 & 0.0292 \\
\hline C - -6.267 & 3.1899 & -0.2418 & C -8.5990 & 0.1028 & -0.1352 & C -7.5899 & -0.3812 & 2.2096 \\
\hline H - -0.235 & -1.8872 & -1.4140 & H 0.1693 & -1.6425 & 1.5532 & H 0.2077 & -2.0177 & 1.1192 \\
\hline H - -1.283 & -0.5109 & -1.7498 & H 1.3267 & -0.3480 & 1.8368 & H 1.2825 & -0.7208 & 1.6274 \\
\hline H - -0.328 & 1.3779 & 1.4061 & H 0.3938 & 1.6152 & -1.2679 & H 0.3794 & 1.6247 & -1.2089 \\
\hline H - 1.408 & 0.0043 & 1.6501 & H 1.3615 & 0.1678 & -1.5652 & H 1.4443 & 0.2858 & -1.6283 \\
\hline H 0.235 & -1.8874 & 1.4138 & H -1.3267 & 0.3480 & 1.8368 & H -0.2358 & -1.3713 & -1.8835 \\
\hline H 1.283 & -0.5113 & 1.7500 & H -0.1693 & 1.6425 & 1.5532 & H -1.3871 & -1.7880 & -0.6223 \\
\hline H 0.329 & 1.3780 & -1.4058 & H -0.3938 & -1.6153 & -1.2678 & H - 0.3623 & 0.9617 & 1.7575 \\
\hline H 1.408 & 0.0044 & -1.6498 & H -1.3615 & -0.1678 & -1.5652 & H - 1.3513 & 1.4652 & 0.3870 \\
\hline H 7.226 & -2.8182 & -0.2974 & H 7.0002 & -3.0926 & -0.4157 & H -4.3253 & -0.6793 & 3.0467 \\
\hline H 9.454 & -1.6681 & -0.1838 & H 6.6151 & 4.0428 & 0.2781 & H 7.1846 & -2.8117 & -0.6675 \\
\hline H 9.547. & 0.7965 & 0.0530 & H -4.3688 & -3.0806 & 0.1937 & H 6.3488 & 4.1162 & 1.0205 \\
\hline H 8.403 & 2.9742 & 0.2509 & H 9.3104 & -2.1129 & -0.3637 & H 9.4283 & -1.7318 & -0.3531 \\
\hline H 4.124 & 3.1435 & 0.1837 & H 9.5938 & 0.3358 & -0.1141 & H 4.1689 & 3.0600 & 0.6845 \\
\hline H 6.289 & 4.2726 & 0.3252 & H 8.6229 & 2.5904 & 0.1322 & H 9.5554 & 0.6659 & 0.2580 \\
\hline H -4.124 & 3.1435 & -0.1838 & H -6.6151 & -4.0428 & 0.2781 & H 8.4432 & 2.8073 & 0.7722 \\
\hline H - 7.226 & -2.8182 & 0.2972 & H -7.0002 & 3.0926 & -0.4157 & H -7.0252 & 0.9680 & -2.9031 \\
\hline H -9.454 & -1.6681 & 0.1833 & H -8.6229 & -2.5903 & 0.1322 & $H-6.5600$ & -0.8727 & 4.0207 \\
\hline H -9.547. & 0.7965 & -0.0536 & H 4.3688 & 3.0806 & 0.1937 & H -9.3226 & 0.8031 & -1.9062 \\
\hline H -8.403 & 2.9742 & -0.2514 & H -9.3104 & 2.1129 & -0.3637 & H -9.5786 & 0.1689 & 0.4751 \\
\hline H -6.289 & 4.2725 & -0.3259 & H -9.5938 & -0.3358 & -0.1141 & H -8.5832 & -0.4553 & 2.6447 \\
\hline
\end{tabular}

